\title{
RECONCILING MONETARY POLICY AND THE INSTITUTIONAL STRUCTURE
}

\author{
Murray L. Weidenbaum
}

Most of the critics of the monetarist approach to fighting inflation are on the left, advocating various extensions of government power over private wage and price decisions. My own inclination being to tilt to the right, this critique is aimed from that ead of the policy spectrum. Hopefully, it will be taken as a constructive proposal.

Lest I be misunderstood, I am well aware of the power of monetary policy to influence the level of nominal, that is monetary, income or output and I am a strong advocate of its use. As a sometime participant in the policy making process, however, I am also well aware of the very powerful constraints that operate to inhibit monetary policy decision makers. The key constraint, both conceptual and political, I will call the $Z$ factor - - which I define as the portion of the change in nominal output that is price; one minus $Z$, of course, is the portion of the change in nominal output that is "real." (Why $z$ ? Because it is the last letter of the alphabet and perhaps a last recourse.)

My concern is based on the painful knowledge that, in the early stages of a program of monetary restraint, the $z$ factor tends to be high. That is, the major initial impact of a slower growth in the

Dr. Weidenbaum is Director of the Center for the Study of American Business at Washington University in St. Louis. 
money supply tends to be lower real output rather than reduced inflation. That relationship should not surprise us. We have learned in specific areas of the economy that short run responses to price and income changes are smaller than long run adjustments. For example, it is now generally agreed that the price elasticity of the demand for energy is much lower in the short run than in the long run.

To be sure, continuation of a policy of monetary restraint -such as a stable growth of the money supply over a sustained period of time - will result in a change in expectations and in business and consumer decision making and thus in a subsequent decline in the $Z$ factor.

However, it is in the short run that political forces enter, and for fairly sensible reasons. When the short term effects of monetary restraint lead to a rise in unemployment, a shift in national priorities usually follows, from curbing inflation to reducing joblessness. In general, those political pressures effectively prevent the monetary authorities from continuing the posture of restraint which, if it had been maintained long enough, could have altered expectations, reduced the $Z$ factor, and yielded the results generally desired by society. Indeed, expectations generally are based on the workings of this cycle in political economy.

Incomes policies, of course, attempt to provide an answer to this dilemra. We need to recognize the basic reason that incomes policies -both voluntary and compulsory, both here and abroad -- have been resorted to. It is hardly because we as a nation like to interfere with private 
decision making or that the citizenry is enamored with the success of government intervention. Rather it is that citizens and policy makers have not been satisfied with the apparent results of indirect measures such as monetary and fiscal policy and will support at times a more activist policy stance. But a more satisfying approach than incones policy experiments, however, may be to change the size of $z$, especially in the short run.

As has been amply demonstrated in the recent 1iterature, there is a myriad of government legislation, rules, and expenditures which interfere with competition, raise prices, or restrict the supply of factors and products. These range from government determination of "prevailing" wages to restrictions on the use of transportation faci7ities to supports of product prices to limitations on imports. But the concern I raise here is not the conventional one of economic freedom and efficiency (which I personally share), but the large welfare costs of these government activities, viewed in terms of the unemployment that results from their interference with the workings of macroeconomic policy. The changes that 1 have in mind are in terms of moving toward a more competitive market economy in which labor and product markets would be more price-elastic than is presently the case. There are several routes that can be followed simultaneously in pursuing this objective -conventional antitrust policy, regulatory reform, and a reduction in the whole range of government subsidies.

In the antitrust area, one specific approach comes to mind -- reducing the various statutory "immunities" from antitrust prosecution. We could do well to lift the exemptions from the competitive norm now 
extended to many product markets, such as interstate trucking, mi marketing, maritime activities, etc. Moreover, it may be time to think about the unthinkable -- reducing the broad immunity extended to most labor union activities, which covers so many aspects of product as well as labor markets.

In the area of government regulation, we only need to refer to the expanding literature on the excessive costs of many regulatory activities and the ways to reduce their negative impacts. It is important, moreover, to view these governmenta]ly-imposed impediments in a dynamic sense. In a static world, the one-shot elimination of costly government regulation would have only a one-period effect on the inflation rate. But in the real world of government policy making, we are faced with the phenomenon of a rapidly expanding network of regulatory requirements. Viewed in that 1 ight, a regulatory reform effort which is steadily bringing down the costs that would otherwise be imposed on the private sector would yield rising returns over an extended period of time.

The current concern with reducing or at least slowing down the size of government could well focus on the various subsidies embedded in procurement, credit, and expenditure programs -- subsidies which shelter numerous groups from market forces and make more difficult and expensive the access to those products and markets by the rest of the population. The supply of factors and products has been restricted by such government subsidies as production and import quotas and generous government stockpiles of minerals and metals. The opportunities for reducing the $Z$ factor are as exciting as they are numerous. 
of course, these microeconomic structural and institutional changes must be seen as supplements to appropriate monetary and fiscal policy. Indeed, these changes would enhance the effectiveness of these traditional macroeconomic tools.

Overcoming the natural reluctance to cite one's own earlier work, I recall the conclusions of an article in a 1972 issue of the Review of Economics and Statistics in which I wrote that, over the coming decade, this nation may be increasingly resorting to greater controls over wage and price decisions in imperfect factor and product markets, unless we take strong actions to reduce those market imperfections. "...the choice may well be between fostering a greater degree of competition in private markets or relying more heavily on government controls over private decision making." Wistfully and reluctantly, I repeat my earlier conclusion as a forecast for the next decade. 